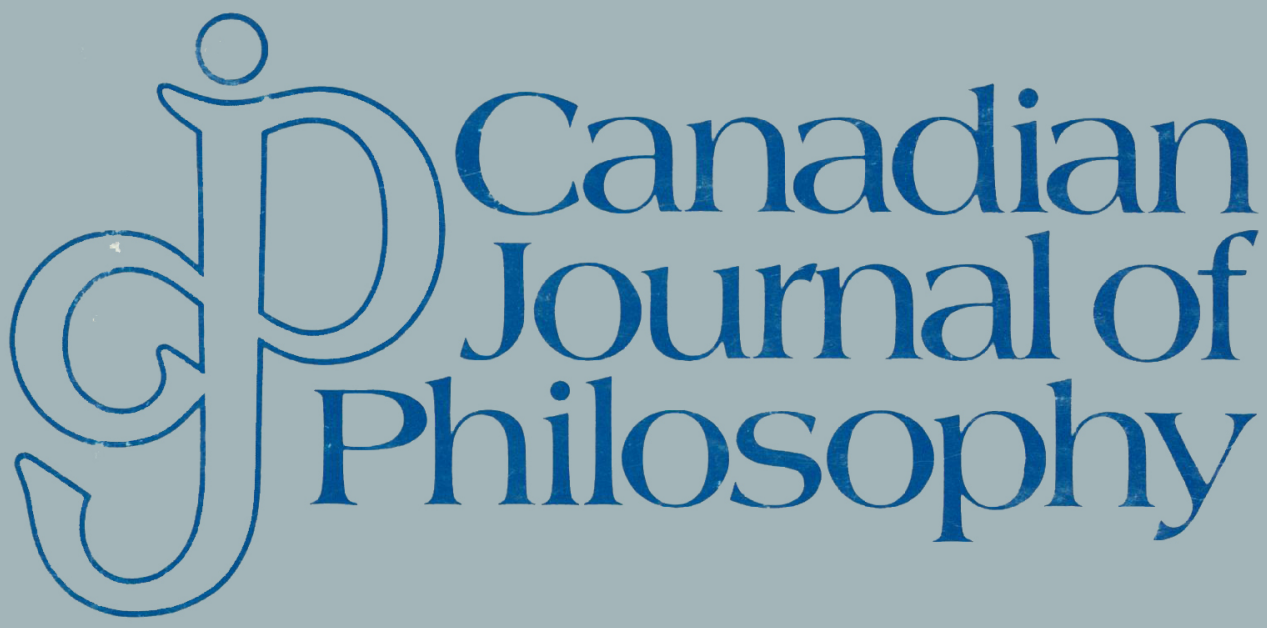

SYMHOSIUM ON CHARLES TAYLOR'S

HUMAN AGENC' ANI) LANGIIGE

SEIZING THE HEIDGEHOG BY THE TAIL

Romald de Sousa

(HARLFS TAYIOR ON EXPRESSION A.VI)

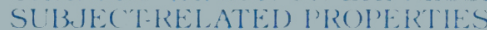

Sicuent Datis

REPLY TO DE SOUSA AND IDAVIS

(harle's Taulor

A (AUSAL THEORY OF EXPERIENTIAI. FEAR

Wayne Datis

IMAGINING EMOTIONS ANi)

APPRECIATING FICTION

Susan l. Feagin

ARISTOTLE:S REALISM

Martin Theredale

RIGIITS BASEI) PARETIANISM

leter Vallentume

RECENT AUSTRALIAN WORK IN PHIIOSOPIIY

Robert Brow'll

CRITICAL NOTICE OF CHARLES TAYLOR.

HUMAN AGENCY INI) LANGIIAGE

Michael slote

CRITICAL NOTICE OF ('HARLES TAYIOR

PHILOSOPHY ANL TIIE IILMAN SCIENCES

Anmette (. Baice

('RITICAL NOTICE OF

J.L. MA(KIE. PERSONS ANI) VALUES ANI)

TED HONIDERICH, MORALITY ANI) OBSIE TIITT

Peter vallemunte

CRITICAL NOTICE OF SOOTT AUSTIN

PARMENIIEES: BEING. BOL VISS ANI LOCIK

Joseph (owe'ls 


\section{Editors/ Rédaction}

\section{Board of} Referees/

Comité de Lecture
DAVID COPP, Simon Fraser University

MARSHA P. HANEN, University of Calgary

PHILIP P. HANSON, Simon Fraser University

JOHN KING-FARLOW, University of Alberta

BERNARD LINSKY, University of Alberta

MOHAN MATTHEN, University of Alberta

KAI NIELSEN, University of Calgary

ROBERT WARE, University of Calgary

RONALD M. YOSHIDA, University of Lethbridge, Directeur Administratif/Administrative Editor

JOHN A. BAKER, University of Calgary,

Directeur des Recensions/Book Review Editor

ANNE WILLIAMS, University of Lethbridge,

Secrétaire de Rédactions/Executive Secretary

BRENDA BAKER, University of Calgary,

Directrice de la Publication/Managing Editor

Rodger Beehler, University of Victoria

J.A. Brook, Carleton University

Robert Burch, University of Alberta Adèle Chené, Université de Montréal Yvan Cloutier, Collège de Sherbrooke Steven Davis, Simon Fraser University Rolf George, University of Waterloo John W. Heintz, University of Calgary Bruce Hunter, University of Alberta Thomas Hurka, University of Calgary Ali Akhtar Kazmi, University of Calgary E. Levy, University of British Columbia Andrew Lugg, University of Ottawa Dennis McKerlie, University of Calgary F.J. Pelletier, University of Alberta Peter Schouls, University of Alberta Roger A. Shiner, University of Alberta Béla Szabados, University of Regina

Second Class mail registration number $2690 /$

Courrier de deuxième classe-Enregistrement no. 2690

-1988 Canadian Journal of Philosophy 


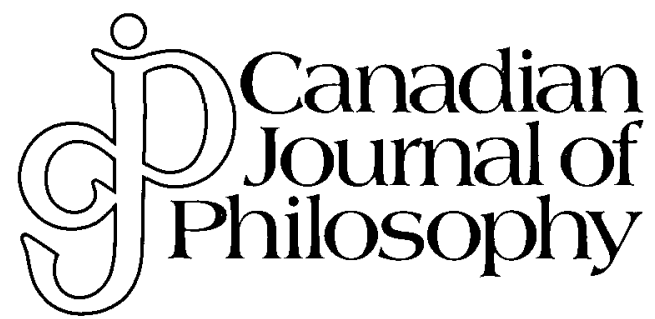




\section{TABLE OF SYMPOSIUM ON CHARLES TAYLOR'S CONTENTS HUMAN AGENCY AND LANGUAGE}

SEIZING THE HEDGEHOG BY THE TAIL

Ronald de Sousa

CHARLES TAYLOR ON EXPRESSION AND

SUBJECT-RELATED PROPERTIES

Steven Davis

REPLY TO DE SOUSA AND DAVIS

Charles Taylor

A CAUSAL THEORY OF EXPERIENTIAL FEAR Wayne Davis

IMAGINING EMOTIONS AND

APPRECIATING FICTION

Susan L. Feagin

ARISTOTLE'S REALISM

Martin Tweedale

RIGHTS BASED PARETIANISM

Peter Vallentyne

RECENT AUSTRALIAN WORK IN PHILOSOPHY Robert Brown

CRITICAL NOTICE OF CHARLES TAYLOR, HUMAN AGENCY AND LANGUAGE

Michael Slote

CRITICAL NOTICE OF CHARLES TAYLOR, PHILOSOPHY AND THE HUMAN SCIENCES

CRITICAL NOTICE OF J.L. MACKIE, PERSONS AND VALUES AND TED HONDERICH, MORALITY AND OBIECTIVITY

Peter Vallentyne

CRITICAL NOTICE OF SCOTT AUSTIN, PARMENIDES: BEING, BOUNDS, AND LOGIC Joseph Owens

Notes on Contributors/Sur les Collaborateurs

Information for Authors/Avis aux Auteurs

Subscription Information/Abonnements

Other Business Information/

Services administratifs - détails supplementaires 